\title{
FAKTOR-FAKTOR KESULITAN BELAJAR MATA PELAJARAN IPS EKONOMI KELAS XI DI SMAN 2 KATINGAN HILIR
}

\author{
Oleh \\ Tri Wahyudi, ${ }^{*}$ Santi Endriani** \\ Email:santiendriyani@gmail.com
}

\begin{abstract}
This study aims to determine the factors that cause learning difficulties of the XI-class Economics Social Sciences course at SMAN 2 Katingan Hilir. This study uses descriptive quantitative methods. The population in this study were all students of class XI IPS-1 and class XI IPS-2, which numbered 48 participants in the study. This study is a population study. the instruments used in this study were questionnaires. Based on the data the researchers collected was analyzed using a percentage formula. Based on the presentation of the data, it is obtained a general description of the factors of learning difficulties of Social Sciences Economics subjects in class XI at SMAN 2 Katingan Hilir namely internal factors, motivational indicators with a dominant category of $70.5 \%$, attention indicators with less dominant categories of $42 \%$, indicators interest with the dominant category is $62.5 \%$, the memory indicator with the less dominant category is $44 \%$.
\end{abstract}

(C) Muhammadiyah University Palangkaraya

Keywords: Learning Difficulties, Social Sciences, Economics

\begin{abstract}
ABSTRAK
Penelitian ini bertujuan untuk mengetahui faktor-faktor penyebab kesulitan belajar matapelajaran IPS Ekonomi kelasXI di SMAN 2 Katingan Hilir. Penelitian ini menggunakan metode deskriptif kuantitatif. Adapun populasi dalam penelitian ini adalah seluruh peserta didik kelas XI IPS-1 dan kelas XI IPS-2 yaitu yangberjumlah 48 orang pesertadidik .Penelitian ini merupakan penelitian populasi. nstrumen yang digunakan dalam penelitian ini adalah berupa angket. Berdasarkan data yang peneliti kumpulkan dianalisis menggunakan rumus persentase. Berdasarkan penyajian data, maka diperoleh gambaran secara umum tentang faktor kesulitan belajar mata pelajaran IPS Ekonomi kelas XI di SMAN 2 Katingan Hilir yaitu Faktor internal, indicator motivasi dengan kategori dominan yakni $70,5 \%$, indicator perhatian dengan kategori kurang dominan yakni $42 \%$, indicator minat dengan kategori dominan yakni $62,5 \%$, indicator ingatan dengan kategori kurang dominan yakni $44 \%$.
\end{abstract}

(CUniversitas Muhammadiyah Palangkaraya

Kata Kunci: Kesulitan Belajar, IPS, Ekonomi

Tri Wahyudi* Mahasiswa FKIP UM Palangkaaraya

Santi Endriani** Dosen Universitas Muhammadiyah Palangkaraya 


\section{PENDAHULUAN}

Belajar merupakan kewajiban setiap manusia yang berlangsung seumur hidup, tidak ada alasan untuk tidak belajar.Hal ini telah disikapi oleh pemerintah Negara Republik Indonesia dengan menempatkan belajar pada Undang-Undang Dasar

1945. Kesemuanya itu mempunyai satu tujuan yaitu meningkatkan mutu luaran dari proses pendidikan.

Pemerintah merumuskan dalam Undang-Undang Republik Indonesia No. 20 tahun 2003 tentang Sistem Pendidikan Nasional yang menjelaskan bahwa pendidikan dilakukan agar mendapatkan tujuan yang diharapkan bersama yaitu: Pendidikan nasional berfungsi mengembangkan kemampuan dan membentuk watak serta peradaban bangsa yang bermartabat dalam rangka mencerdaskan kehidupan bangsa, bertujuan untuk berkembangnya potensi belajar peserta didik agar menjadi manusia yang beriman dan bertakwa kepada Tuhan Yang Maha Esa, berakhlak mulia, sehat, berilmu, cakap, kreatif, mandiri, dan menjadi warga negara yang demokratis serta bertanggung jawab. Peserta didik merupakan unsur terpenting dalam suatu proses kegiatan belajar mengajar. Setiap guru berkeinginan agar peserta didik memperoleh hasil belajar yang optimal. Namun pada kenyataannya, tidak semua peserta didik mendapatkan hasil yang diharapkan. Orang tua, masyarakat, dan peserta didikitu sendiri mungkin tidak mengetahui apa yang mengakibatkan hal ini terjadi.Hal itu juga sejalan dengan pendapat Nana Sujana (2010:1) dalam pelaksanaan pendidikan di sekolah ada tiga variable yang saling berkaitan. Ketiga variabel tersebut adalah kurikulum, guru dan proses belajar mengajar. Dalam hal ini guru menempati kedudukan sentral sebab peranannya sangat menentukan. Guru harus mampu menerjemahkan nilai- nilai yang ada dalam kurikulum kemudian mentransformasikan nilainilai tersebut kepada siswa melalui proses belajar mengajar di sekolah. Setiap peserta didik pada prinsipnya berhak memperoleh peluang untuk mencapai hasil akademik yang memuaskan. Namun, pada kenyataannya, kita mengetahui perbedaan masing-masing peserta didik dalam hal kemampuan intelektual, kemampuan fisik, latar belakang keluarga, kebiasaan dan pendekatan belajar yang terkadang sangat mencolok antara peserta didik dengan peserta didik lainnya. Nilai ulangan harian maupun semester peserta didik masih dibawah nilai ketuntasan di SMAN-2 Katingan Hilir, nilai mereka masih di bawah 70 minimal nilai Kriteria Ketuntasan Minimal (KKM) belajar. Dari hasil wawancara peneliti kepada guru mata pelajaran IPS ekonomi SMAN-2 Katingan Hilir, peserta didik kurang memiliki kemauan bekerja keras untuk meraih keberhasilan prestasi belajar. Mereka umumnya hanya belajar saat menhadapi ujian, jarang sekali melakukan studi atau belajar secara rutin.

Sukri (2009: 123) mengemukakan bahwa masih cukup banyak peserta didik yang mempunyai cara belajar kurang baik seperti belajar dengan 
waktu yang tidak teratur (tidak memiliki jadwal), belajar sambil nonton TV atau mendengarkan radio, melakukan belajar dengan berpindah-pindah, sering terlambat masuk sekolah, dan hanya belajar pada waktu menghadapi ulangan saja.Metode yang digunakan dalam penyampaian materi masih menggunakan metode ceramah. Hal ini menimbulkan kejenuhan pada peserta didik,sehingga mengurangi keseriusan dan motivasi mereka dalam belajar. Menurut Slameto (2010:78) bahwa motivasi erat sekali hubungannya dengan tujuan yang akan dicapai dalam belajar, di dalam menentukan tujuan itu dapat disadari atau tidak, akan tetapi untuk mencapai tujuan itu perlu berbuat, sedangkan yang menjadi penyebab berbuat adalah motivasi itu sendiri sebagai daya penggerak atau pendorongnya.

Jadi, dari pendapat di atas dapat diasumsikan bahwa motivasi peserta didik dalam proses belajar mengajar, sangat mempengaruhi prestasi belajar peserta didik. Dengan demikian prestasi belajar siswa dapat berdampak positif jika peserta didik itu sendiri mempunyai kesiapan dalam menerima suatu mata pelajaran dengan baik.

Prestasi belajar yang memuaskan dapat diraih oleh setiap peserta didik jika mereka dapat belajar secara wajar, terhindar dari berbagai ancaman, hambatan dan gangguan. Namun ancaman, hambatan, dan gangguan tersebut dialami oleh peserta didik tertentu sehingga mereka mengalami kesulitan dalam belajar. Pada tingkat tertentu memang ada peserta didik yang dapat mengatasi kesulitan belajarnya tanpa harus melibatkan orang lain. Tetapi pada kasus-kasus tertentu, peserta didikbelum mampu mengatasi kesulitan belajarnya maka bantuan guru atau orang lain sangat diperlukan oleh peserta didik.

Dunia pendidikan mengartikan diagnosis kesulitan belajar sebagai segala usaha yangdilakukan untuk memahami dan menetapkan jenis dan sifat kesulitan belajar. Juga mempelajarifaktor-faktor kesulitan belajar serta cara menetapkan dan kemungkinanmengatasinya, baik secara kuratif (penyembuhan) maupun secara preventif (pencegahan) berdasarkan data dan informasi yang seobyektif mungkin (Gemari, 2011: 57). Berdasarkan latar belakang tersebut di atas, maka peneliti tertarik untuk melakukan penelitian mengenai Faktor Kesulitan Belajar mata pelajaran IPS Ekonomi kelas XI di SMAN 2 Katingan Hilir.

Tujuan dari penelitian ini adalah: mengetahui faktor-faktor internal penyebab kesulitan belajar mata pelajaran Ekonomi pada peserta didik SMA Negeri 2 Katingan Hilir.

\section{METODE PENELITIAN}

Metode penelitian yang dilakukan adalah penelitian kualitatif dengan pedekatan deskriptif. Denzim dan Lincoln (dalam Moleong, 2009:5) menyatakan bahwa penelitian kualitatif adalah penelitian yang menggunakan latar alamiah, dengan maksud menafsirkan fenomena yang terjadi dan dilakukan dengan jalan melibatkan metode yang ada. 
Sedangkan menurut Sugiyono (2010: 6) menjelaskan bahwa Metode Penelitian adalah cara- cara ilmiah untuk mendapatkan data yang valid, dengan tujuan dapat ditemukan, di kembangkan dan di buktikan, suatu pengetahuan tertentu sehingga pada gilirannyadapat digunakan untuk memahami, memecahkan, dan mengantisipasi masalah. Sejalan dengan pendapat di atas metode penelitian yang digunakan dalam penelitian ini adalah penelitian deskriptif.

Kemudian Whitney berpendapaat (2010: 61), metode deskriptif adalah pencarian fakta dengan interpretasi yang tepat. Penelitiandeskriptif mempelajari masalah- masalah dalam masyarakat, serta tatacara yang berlaku salama masyarakat serta situasi-situasi tertentu, termasuk tentang hubungan kegiatan, sikap, pandangan, serta proses-proses yang sedang berlangsung dan pengaruh dari suatu fenomena. Penelitian deskriptif adalah metode penelitian yang berusaha menggambarkan objek atau subjek yang diteliti sesuai dengan apa adanya (Best, 2010:119).

Adapun tujuan dari penelitian deskriptif adalah untuk membuat penelitian secara sistematis, factual, dan akurat mengenai fakta dan sifat populasi atau daerah tertentu.

\section{HASIL DAN PEMBAHASAN}

Berdasarkan hasil penelitian dan analisis data yang diperoleh dari hasil pengumpulan data dengan penyebaran teknik angket yang dilaksanakan di kelas XI IPS1 dan IPS2 SMAN 2Katingan Hilir dari 16 item pertanyaan yang sudah dianalisis dan dari hasil rekapitulasi data di atas maka faktor kesulitan belajar mata pelajaran IPS Ekonomi kelas XI di SMAN 2 Katingan Hilir.adalah sebagai berikut :

\section{Tabel 1}

Rekapitulasi Data Hasil Penelitian

Tentang Faktor kesulitan belajar mata pelajaran IPS Ekonomi kelas XI di SMAN 2 Katingan Hilir

\begin{tabular}{|l|l|l|l|}
\hline No & Indikator & Presentasi & Kriteria \\
\hline 1 & Motivasi & $70,5 \%$ & Dominan \\
\hline 2 & Perhatian & $42 \%$ & Kurang Dominan \\
\hline 3 & Minat & $62,5 \%$ & Dominan \\
\hline 4 & Ingatan & $44 \%$ & Kurang Dominan \\
\hline
\end{tabular}

faktor penyebab rendahnya kemampuan kemampuan kesulitan belajar mata pelajaran IPS Ekonomi kelas XI di SMAN 2 Katingan Hilir.dalam karangan untuk kategori sangat dominan adalah dari faktor internal yaitu pada indikator motivasi $(70,5 \%)$ merupakan faktor kesulitan belajar mata pelajaran IPS Ekonomi kelas XI di SMAN 2 Katingan Hilir, sedangkan faktor internal pada indikator perhatian, minat, dan ingatan bukan merupakan faktor penyebab kesulitan belajar mata pelajaran IPS Ekonomi kelas XI di SMAN 2 Katingan Hilir. Dengan demikian faktor internal kesulitan belajar mata pelajaran IPS Ekonomi kelas XI di SMAN 2 Katingan Hilir dipengaruhi oleh cara guru mengajar.

\section{KESIMPULAN}

Berdasarkan penyajian dan analisis data tentang penyebab kesulitan belajar mata pelajaran IPS Ekonomi pada bab IV, maka peneliti menyimpulkan secara umum tentang faktor kesulitan belajar mata pelajaran 
IPS Ekonomi kelas XI di SMAN 2 Katingan Hilir adalah faktor internal, yaitu :

1. Motivasi, 70,5 Dominan

2. Perhatian, 42 Kurang Dominan

3. Minat, 62,5 Dominan

4. Ingatan, 44 Kurang Dominan Jadi, faktor internal penyebab kesulitan belajar mata pelajaran IPS Ekonomi terdapat pada indikator motivasi dengan kategori Dominan pada sub indikator Apakah kamu sering belajar kelompok dengan temanmu untuk mendiskusikan tentang materi pelajaran agar lebih mudah dipahami.

\section{DAFTAR PUSTAKA}

Gemari,2011.Analisis Kebijakan Pendidikan Suatu Pengantar Bandung: Rosdakarya

Lexy J. Moleong, 2009. Metodologi Penelitian Kualitatif, Bandung : Remaja Rosdakarya

Nana Sudjana, 2010. Dasar-Dasar Proses Belajar Mengajar. Bandung: Sinar Baru Algensindo,

Slameto, 2010. Belajar Dan FaktorFaktor Yang Mempengaruhinya. Jakarta: Bumi Renika Cipta.

Sugiyono, 2010. Metode Penelitian Pendidikan. Bandung : Alfabeta

Sukri, 2009. Manajemen Teori, Praktik, dan Riset Pendidikan. Jakarta: BumiAksara

Undang-Undang RI. 2003. Depertemen Pendidikan Nasional, Jakarta. 